\title{
THYROID STATUS, MAJOR AND TRACE ELEMENTS CONTENT IN PATIENTS WITH AUTOIMMUNE THYROIDITDIS LIVING IN CHERNOBYL-AFFECTED AREAS OF ZHYTOMYR REGION ${ }^{\star}$
}

\author{
I. A. Luzanchuk ${ }^{1}$, V. I. Kravchenko¹, M. O. Polumbryk ${ }^{2}$, Yu. M. Tarashchenko \\ ${ }^{1}$ Institute of endocrinology and metabolism of NAMS of Ukraine, Kyiv, Ukraine; \\ ${ }^{2}$ National University of food technologies, Kyiv, Ukraine \\ igorluz@bigmir.net
}

Autoimmune thyroiditis (AIT) is an important disease of the endocrine system which increases AIT an alarming rate [1-2]. The most important contributors of AIT are environment pollution, imbalanced iodine intake, several medical drugs, and other factors which may affect immune system and cause autoimmune injuries of thyroid gland. There was strong correlation between incidences of AIT and air pollution [3]. As a result, there has been a thyrocytes dead, increased rate of hypothyreosis incidences, and finally necessity of therapy by thyroid hormones during the life. AIT had high prevalence in whose regions of Ukraine, where lived people with increased incidences of goiter [1-3]. Thus, it is necessary to study factors which may cause AIT in region with high radioactive pollution and increased number of people with endemic goiter.
Essential trace elements play the important roles in the enzymatic processes regulation and thyroid hormones synthesis in thyroid glands. It is important, that the most of these elements are a part of immune system, which has changed after autoimmune disorders of the thyroid gland.

Recently, our studies performed in Kyiv region have shown that people after Chernobyl disaster had decreased levels of several essential trace elements in blood serum [4]. The purposes of this study are to determine concentrations of calcium, magnesium, iodine, selenium, iron, copper, and zinc in individuals with autoimmune thyroiditis and control group as well as to find out associations between concentrations of the trace elements and levels of radioactive irradiation among people living in Zhytomyr region.

* The research was carried out as part of investigation work at the Department of epidemiology of endocrine diseases, Institute of endocrinology and metabolism of National Academy of medical sciences of Ukraine «Iodine status and antioxidant system activity in the presence of iodine deficiency in the thyroid gland» (State registration number: 0116U002152).

Institution, which financed the research: National Academy of medical sciences of Ukraine.

The authors assume responsibility for the published work.

The authors guarantee absence of competing interests and their own financial interest when carrying out the research and writing the article.

The manuscript was received by the editorial staff 18.02.2020. 


\section{MATERIALS AND METHODS}

Subjects. Sixty one individuals (30 males and 31 females) aged from 29 to 46 years residing in Zhytomyr region of Ukraine were examined. Sixteen patients ( 8 males and 8 females) with the mean age of $38.4 \pm 1.2$ were diagnosed as suffering from autoimmune thyroiditis (AIT) and showed high levels of Thyroglobulin (TG) and TPOAb (antibodies to thyroperoxidase) in blood serum. A control group of 45 individuals (22 males and 23 females) with a mean age of $38.5 \pm 0.8$ yrs living in the same region had no history of autoimmune diseases prior to the investigations and characterized by TPOAb and TG antibodies (TgAbs) levels in blood serum within the reference ranges. The individuals mentioned above participated in the cohort of US-Ukrainian-Belorussian collaborative project, and their blood samples were obtained from the database. Irradiation doses by ${ }^{131} \mathrm{I}$ of thyroid glands were measured by experienced dosimetrists in the first two month just after Chernobyl disaster, by means of the transport model of ${ }^{131}$ I uptake by human organism from environment and interview data [5-6]. These parameters were also obtained from the database of the project mentioned above.

Analysis. Ultrasonographic observations of the thyroid volume were performed using a real-time portable scanner (Terason 2000, Burlington, MA, USA) with linear transducer, and frequency of $10 \mathrm{MHz}$. Details of echostructure and echogenicity were recorded. The thyroid volume was calculated based on the volume of ellipsoid as described by Brunn [7]. Thyroid volumes greater than $15 \mathrm{~mL}$ in men and $13 \mathrm{~mL}$ in women were recorded as goiter.

Thyroid gland functionality was assessed by concentrations of TSH (thyroid stimulating hormone) and FT4 (free thyroxine) in serum by radioimmunoassay analysis using reagent pack (Amersham, U.K.). Concentration of TG, TgAbs, and TPOAb were measured in serum by LUMitest immunochemiluminescence assays (BRAHMS Diagnostica GMBH, Heningsdorf, Germany) using a Bertholdt 953 luminometer (Pforzheim, Germany).

Iodine concentrations in urine were measured by the Sandell-Kolthoff reaction with
Dunn modification [8]. The obtained results were interpreted according to WHO recommendations [9].

Our laboratory participated in the external quality control for urinary iodine of EQUIP (Ensuring the Quality of Urinary Iodine Procedures) standardization program of the Centers for Disease Control and Prevention (Atlanta, USA).

Concentrations of calcium, magnesium, zinc, copper, iron, and selenium in serum were determined by atomic optical emission spectrometry coupled by inductively coupled plasma (ICP-OES, Perkin-Elmer, model Optima 2100, USA) according to the original procedure approved by Institute of Occupational Medicine of the NAMS of Ukraine.

Multi-element standard solution (Merck, Germany, catalog number 111355.0100) containing 23 elements was used to build a calibration curve for $\mathrm{Ca}, \mathrm{Mg}, \mathrm{Fe}, \mathrm{Se}, \mathrm{Cu}$, and $\mathrm{Zn}$ in the ICP-OES analysis.

The system was calibrated using ICP standard solution of 23 chemical elements (\# 111335, Merck, Germany).

Reference ranges for magnesium, calcium, zinc, iron, copper, and selenium were considered respectively as $17-28 \mathrm{mg} / \mathrm{L}, 90-112 \mathrm{mg} / \mathrm{L}$, $0.6-1.2 \mathrm{mg} / \mathrm{L}, 0.6-1.68 \mathrm{mg} / \mathrm{L}, 0.7-1.55 \mathrm{mg} / \mathrm{L}$, and $0.046-0.14 \mathrm{mg} / \mathrm{L}[10]$.

Statistical analysis. Statistical analysis was performed according to the demands of the modern practical medicine and biostatistics, using non-infection epidemiology approaches [11-12]. SPSS 11.0 and Medstat Pack were used for the statistical analysis. The experimental data were given as mean $\pm \mathrm{SE}$, median, and quartiles due to their non-normality of distribution of experimental variables. The correlations between experimental variables were was evaluated using Spearman`s rank correlation coefficients.

Mann-Whitney U-tests were was implemented for non-parametric variables. The risk of autoimmune tyreoditis in both groups was estimated by relative risk (RR) and its $95 \%$ confidence interval $(95 \% \mathrm{CI})$. The p values less than 0.05 were considered statistically significant. 


\section{RESULTS AND DISCUSSION}

Thyroid gland volume measured by ultrasonography assay shown, that the mean size of thyroid gland in control group was within normal range $(10.3 \pm 0.5 \mathrm{ml}$, median $10.1 \mathrm{ml})$, while patients with AIT characterized by compaction of the thyroid gland parenchyma during palpation and overall changes of the ultrasound images (hypoechoic and heterogeneous thyroid gland tissue). We observed enlargement of thyroid glands in patients with AIT (mean volume of thyroid glands was $15.7 \pm 1.2 \mathrm{ml}$ and median $=15.7, \mathrm{p}<0.001)$ in compare to control group.

Also, activation of the immune processes in thyroid gland was observed in AIT group. The concentration of TPOAb in blood serum of patients with AIT was 41-489 fold higher than TPOAb in the control group.

The mean concentration of iodine in urine in the patients with AIT was significantly different from control group (Table 1). It should be noted that $28.8 \%$ of individuals in the control group and only $6.3 \%$ people suffering from AIT had urinary iodine excretion (UIE) greater than, $100 \mu \mathrm{g} / \mathrm{L}$. Also, severe iodine deficiency (UIE $\leq 20 \mu \mathrm{g} / \mathrm{L}$ ) was detected in $4.4 \%$ of volunteers in control group and $6.3 \%$ of patients with AIT. Median and mean UIE were statistically different $(p=0.017)$ in the both groups. In general, the presence of mild iodine deficiency was observed in the control group and AIT subjects living in Zhytomyr region as well.

Thyroglobulin (Tg) level in blood serum as well as FT4 and TSH are the other indicators of iodine consumption. Concentration of $\mathrm{Tg}$ in blood serum is being more sensitive indicator of iodine status and it is generally considered to be a measure of the more prolonged iodine deficiency. We found that AIT was associated with 1.5-fold rise in Tg level in blood serum. Similar findings were observed in the changes of TSH which is less sensitive indicator of iodine deficiency than UIE or Tg (Table 1). Thus, UIE, $\mathrm{Tg}$, and TSH level in blood serum of patients with AIT indicated presence of the prolonged mild iodine deficiency.

The thyroid doses were obtained from the database of the US-Ukrainian-Belorussian collaborative project and analyzed in both groups. Median thyroid doses in the control and AIT group were slightly different 0.5 [0.2-1.7] Gy and $0.3[0.08-0.6]$ Gy, respectively (Table 1). Also we indicate greater values of thyroid doses in men in compare to women $(p=0.071)$.

Concentrations of calcium, magnesium, zinc, iron, copper, and selenium in blood serum in both groups were analyzed. Non-normal distribution of the experimental was observed in the most cases. We indicated mean and median values of the elements concentration in blood

Thyroid dose, UIE, and thyroid status among control group

Table 1 of individuals and AIT subjects of Zhytomyr region

\begin{tabular}{c|c|c|c|c}
\hline \multirow{2}{*}{ Parameter } & \multicolumn{2}{|c|}{ Control group $(\mathbf{n}=45)$} & \multicolumn{2}{c}{ AIT group (n = 16) } \\
\cline { 2 - 5 } & Mean \pm SE & Median [Q1-Q3] & Mean \pm SE & Median [Q1-Q3] \\
\hline UIE $(\mu \mathrm{g} / \mathrm{L})$ & $97.7 \pm 11.8$ & $80.5[41.2-140.5]$ & $51.7 \pm 7.0$ & 51.7 \\
{$[38.2-64.5]^{* *}$} \\
\hline $\mathrm{Tg}(\mu \mathrm{g} / \mathrm{L})]$ & $13.1 \pm 1.3$ & $10.8[7.8-16.1]$ & $19.1 \pm 4.0$ & $14.9[6.9-30]$ \\
\hline $\mathrm{Tvol}(\mathrm{ml})$ & $10.3 \pm 0.5$ & $10.1[8.1-12.5]$ & $15.6 \pm 1.16$ & $15.7[13,6-18,5]^{*}$ \\
\hline $\mathrm{TSH}(\mathrm{mIU} / \mathrm{L})$ & $1.5 \pm 0.2$ & $1.4[0.9-1.9]$ & $2.0 \pm 0.2$ & $2[1.2-2.9]^{* *}$ \\
\hline FT4 $(\mathrm{pmol} / \mathrm{L})$ & $15.6 \pm 0.7$ & $15.6[14.9-16.3]$ & - & - \\
\hline TPOAb $(\mathrm{IU} / \mathrm{ml})$ & $20.8 \pm 2.4$ & $11[3-28]$ & $903.0 \pm 271.5$ & {$[124.8-1465.7]^{*}$} \\
\hline TgAbs $(\mathrm{IU} / \mathrm{ml})$ & $16.1 \pm 2.4$ & $19[10.6-27]$ & $42.0 \pm 16.3$ & $13[4-57.1]$ \\
\hline Thyroid dose, Gy & $2.0 \pm 0.6$ & $0.5[0.2-1.7]$ & $0.6 \pm 0.3$ & $0.3[0.08-0.6]$ \\
\hline
\end{tabular}

[Q1 - Q3] - 25-75 percentile; SE - standart error.

* $\mathrm{P}<0.001$ in compare with control according to Mann-Whitney U-test;

** $\mathrm{P}<0.05$ in compare with control according to Student's criteria. 
Concentrations of elements in serum of patients with AIT and control group of volunteers $(\mathrm{mg} / \mathrm{L})$ living in Zhytomyr region of Ukraine

\begin{tabular}{c|c|c|c|c}
\hline \multirow{2}{*}{ Elements } & \multicolumn{2}{|c|}{ Control (n = 45) } & \multicolumn{2}{c}{ AIT (n = 16) } \\
\cline { 2 - 5 } & Mean \pm SE & Median (Q1-Q3) & Mean \pm SE & Median (Q1-Q3) \\
\hline $\mathrm{Ca}$ & $98.4 \pm 2.5$ & $98.0(87.3-106.8)$ & $73.6 \pm 2.8$ & $74.2^{*}(64.6-79.0)$ \\
\hline $\mathrm{Mg}$ & $20.4 \pm 0.5$ & $20.3(18.3-22.3)$ & $14.8 \pm 0.7$ & $15.2^{*}(12.8-16.5)$ \\
\hline $\mathrm{Zn}$ & $0.71 \pm 0.06$ & $0.64(0.55-0.71)$ & $0.39 \pm 0.03$ & $0.37^{*}(0.305-0.408)$ \\
\hline $\mathrm{Fe}$ & $1.36 \pm 0.095$ & $1.31(0.91-1.79)$ & $1.23 \pm 0.14$ & $1.01(0.88-1.5)$ \\
\hline $\mathrm{Cu}$ & $1.43 \pm 0,057$ & $1.43(1.14-1.59)$ & $0.96 \pm 0.09$ & $0.93^{*}(0.73-1.1)$ \\
\hline $\mathrm{Se}$ & $0.046 \pm 0.003$ & $0.04(0.03-0.054)$ & $0.052 \pm 0.005$ & $0.047(0.03-0.07)$ \\
\hline
\end{tabular}

(Q1-Q3) - 25-75 percentile; SE — standart error.

* $\mathrm{P}<0.001$ in compare with control according to Mann-Whitney U-test.

serum in order to provide comparative analysis with the data obtained by another authors (Table 2).

Calcium plays an important role in genes expression in the immune cells and it can indirectly upset genetic program, including cell proliferation and cell death [13-15]. Concentration of calcium in blood serum was assessed in both groups. We found that calcium level in blood serum was significantly different in the both group. Mean concentration of $\mathrm{Ca}$ in blood serum was $25 \%$ lower than in the control group $(p<0.001)$. We didn't find any gender changes in calcium level in blood serum in both groups. These observations indirectly suggest that $\mathrm{Ca}$ level in blood serum is an important factor in the AIT pathogenesis.

Similar findings were shown in concentrations of $\mathrm{Mg}$ and $\mathrm{Zn}$ in blood serum in the group of AIT and in the control group. The results in table 2 showed that concentrations of magnesium and zinc in blood serum of patients with AIT of both genders (figure 1) were significantly higher as compared to control group ( $p<0.001$ according to Mann-Whitney criteria).

Ions of calcium and magnesium act as the secondary messengers in the regulation of important signaling functions of lymphocytes, including production, differentiating, and cytotoxicity of cytokines as well as affected calcium channels considered as being transporters of $\mathrm{Mg}$ and $\mathrm{Zn}$ [16]. In our opinion, concentration changes of these elements in sera may play an important role in the pathogenesis of the autoimmune processes including AIT.
The mean concentration and median level of zinc was almost two times higher in the control group as compared to AIT subjects. We observed statistically significant $(p<0.001$, according to Mann-Whitney criteria) changes in sera Zn Only $2 \%$ of individuals in the control group had $\mathrm{Zn}$ concentration higher than reference range, while $38.1 \%$ of subjects in this group had zinc level lower than reference range.

Iron plays an important in the regulation of thyroid gland function. In this study we didn't find statistically significant differences in the mean and median concentration of iron in both groups. We found that $7.1 \%$ of subjects in the control group had iron concentration higher than reference range, whereas $28.6 \%$ of individuals in the group were characterized by mild iron deficiency.

Iron plays an important role in the immune system. Immune cells such as macrophages, monocytes, microglia, and lymphocytes are active against bacterial injuries by indirect control of iron regulators including ferroporfyrin and hepcidin [17]. Moreover, lymphocytes participate in the adaptive immunity and iron deficiency or overconsumption may have negative effect on the development of thyroid pathology. In the present study, mean and median concentrations of iron in serum were within the reference range.

Analysis of blood serum revealed that copper concentration was significantly lower in AIT group (Table 2) as compared to control group ( $\mathrm{p}<0.001$, according to Mann-Whitney 
Correlation between content of calcium, magnesium, and trace elements and thyroid status in blood serum in the different observed groups

\begin{tabular}{c|c|c|c|c}
\hline \multirow{2}{*}{$\begin{array}{c}\text { Correlation between } \\
\text { parameters }\end{array}$} & \multicolumn{2}{|c|}{ Control group $(\mathbf{n}=\mathbf{4 5})$} & \multicolumn{2}{c}{ AIT group (n= 16) } \\
\cline { 2 - 5 } & rspearman & $\mathbf{p}$ & rspearman & 0.766 \\
\hline $\mathrm{TSH} / \mathrm{Tg}$ & 0.415 & 0.009 & -0.084 & 0.652 \\
\hline $\mathrm{TSH} / \mathrm{TPOAb}$ & 0.332 & 0.039 & -0.127 & 0.408 \\
\hline $\mathrm{TSH} / \mathrm{Se}$ & 0.425 & 0.009 & -0.231 & 0.045 \\
\hline $\mathrm{Mg} / \mathrm{Ca}$ & 0.569 & $>0.001$ & 0.508 & 0.028 \\
\hline $\mathrm{Mg} / \mathrm{Zn}$ & 0.387 & 0.014 & 0.555 & 0.006 \\
\hline $\mathrm{Ca} / \mathrm{Cu}$ & 0.547 & $>0.001$ & 0.655 & 0.051 \\
\hline $\mathrm{Thyroid} \mathrm{dose/Se}$ & 0.468 & 0.003 & 0.496 & 0.041 \\
\hline $\mathrm{TgAbs} / \mathrm{Tvol}$ & -0.288 & 0.075 & -0.533 & 0.01 \\
\hline $\mathrm{TgAbs} / \mathrm{Tvol}$ & 0.057 & 0.738 & 0.638 & 0.011 \\
\hline $\mathrm{Tv}$ & -0.187 & 0.267 & -0.635 & \\
\hline
\end{tabular}

criteria). We found that $26.2 \%$ of probes in the control group were characterized by $\mathrm{Cu}$ concentration in sera higher than the reference range.

It is known that copper is essential for human immune system, it deficiency may cause neutropenia. The exact mechanism of copper action is still unknown, but it is directly influenced regulatory iron receptors such as hepci$\operatorname{din}[18]$.

The mean concentration of selenium and median level of this trace element in blood serum of patients with AIT and control group were not statistically different. It should be noted, that even in the control group 57.1\% individuals had Se level in blood serum lower than the reference range. Immune system functionality depends on the selenium level in a human diet. Certain Se containing organic derivatives, mainly selenoproteins are important in the processes of inflammation and immunity [19-20].

The correlation of thyroid gland parameters vs essential elements and correlation between the elements were statistically analyzed by linear multiple regression equations (Table 3). The relatively strong correlation was found between TPOAb and TSH $(p<0.05)$, TSH and
Tg $(p<0.01)$, TSH and Se $(p<0.01), \mathrm{Mg}$ and $\mathrm{Ca}(\mathrm{p}<0.01), \mathrm{Ca}$ and $\mathrm{Cu}(\mathrm{p}<0.01), \mathrm{Mg}$ and $\mathrm{Zn}$ $(p=0.014)$ in blood serum in the control group.

In our study, with regard to autoimmune thyroiditis and serum calcium and magnesium levels, magnesium and zinc levels as well as calcium and copper levels, a statistically significant correlation was observed. Moreover, the correlation between TgAbs and magnesium level was found in the AIT group. Also, in the AIT group we detected negative correlation between TgAbs and Tvol in blood serum, and between serum selenium level and Tvol.

Finally, we assessed risk of autoimmune thyroiditis as relative risk (RR) AIT low level of the elements in blood serum in the AIT group. AIT was strongly associated with low magnesium level $(\mathrm{RR}=5.4$, CI 95\%, CI 2.7-7.8, $\mathrm{P}<0.001)$. Likewise, low level of calcium is a strong predictor of AIT, RR was 2.9 (CI 95\%, CI $1.8-3.6, \mathrm{P}<0.001)$. Moreover, low level of zinc in blood serum had 2,3 (CI 95\%, CI 1.6-2.6, $\mathrm{P}<0.01$ ) times the risk of AIT developing. These findings revealed, that macroelements and essential trace elements are influenced the risks of AIT.

\section{CONCLUSIONS}

Analysis of UIE and median Tg level in blood serum indicated, that patients in the group were characterized by mild iodine deficiency, while people in the control group had moderate iodine deficiency. The concentration of $\mathrm{Ca}, \mathrm{Mg}, \mathrm{Zn}$, and $\mathrm{Cu}$ in blood serum in the AIT was significantly lower than concentration of these elements in the control group. The 
present study showed a strong correlation between calcium and magnesium, zinc and mag- nesium, and calcium and copper in serum in the both groups.

\section{REFERENCES}

1. Kravchenko VI, Postol SV. Int J Endocrinol 2011; 35(3): 26-31.

2. Bodnar PM. Endocrinologia: handbook, Vinnytsya, 2007: $344 \mathrm{p}$.

3. Pankiv VI. Diseases of the thyroid gland: monographia, Chernivtsi, 2003: 258 p.

4. Luzanchuk I, Kravchenko VI, Andrusyshyna IM, et al. Int Endocrinol J 2019; 4(15), 290-297. doi: 10.22141/ 2224-0721.15.4.2019.174814.

5. Brenner AV, Tronko MD, Hatch M, et al. Environ Health Perspect 2011; 119(7): 933-939. doi: 10.1289/ehp.1002674.

6. Tronko MD, Brenner AV, Olijnyk VA, et al. J Clin Endocrinol Metab 91(11): 4344-4351. doi: 0.1210/jc.20060498 .

7. Brunn J, Blocjk U, Ruf J, et al. Deutsch Medizin Wochen 1981; 106: 1338-1340.

8. Dunn JT, Grutchfield HE, Gutekunst R, Dunn AD. Methods for measuring iodine in urine: guidance, $\mathrm{Am}$ sterdam, 1993: $71 \mathrm{p}$.

9. Assessment of iodine deficiency disorders and monitoring their elimination : a guide for programme managers. 3rd edition, World Health Organization, 2007: 99 p.

10. Andrusyshyna IM, Lampeka OG, Holub IO, et al. Assessment of trace elements exchange related disorders in workers using ICP-OES: guidance, Kyiv, 2014: 60 p.
11. Bonita R, Beaglehole R, Kjellstrцm T. Basic epidemiology. 2nd ed: guidance, Geneva, 2006: 226 p.

12. Lyakh YE, Gurianov VG. Vestnik of hygiene epidemiol 2004; 8(1): 155-167.

13. Bengsch B, Wherry EJ. Immunity 2015; 42(2), 203-205. doi: 10.1016/j.immuni.2015.01.023.

14. Hogan G, Rao A. Biochem Biophys Res Commun 2015; 460 (1), 40-49. doi: 10.1016/j.bbrc.2015.02.110.

15. Lee MD, Bingham KN, Mitchell TY, et al. Mol Immunol 2015; 63(2): 540-549. doi: 10.1016/j.molimm.2014.10.015.

16. Janeway CA, Medzhitov R. Annu Rev Immunol 2002; 20: 197-216. doi: 10.1146/annurev.immunol.20.083001. 084359 .

17. Cronin S, Woolf CJ, Weiss G, et al. Front Mol Biosci 2019; 6: 116. doi:10.3389/fmolb.2019.00116

18. Gulec S, Collins JF._Annu Rev Nutr 2014; 34: 95-116. doi: 10.1146/annurev-nutr-071812-161215.

19. Percival SS. Nutr Rev 1995; 53(3): 59-66.

20. Avery JC, Hoffmann PR. Nutrients 2018; 10(9): E1203. doi: 10.3390/nu10091203. 


\title{
ТИРЕОИДНЫЙ СТАТУС, СОДЕРЖАНИЕ МАКРО- И МИКРОЭЛЕМЕНТОВ У ПАЦИЕНТОВ С АУТОИММУННЫМ ТИРЕОИДИТОМ ИЗ ПОСТРАДАВШИХ ПОСЛЕ ЧЕРНОБЫЛЬСКОЙ АВАРИИ РАЙОНОВ ЖИТОМИРСКОЙ ОБЛАСТИ
}

\author{
Лузанчук И. А. ${ }^{1}$, Кравченко В. И. ${ }^{1}$, Полумбрик М. О. ${ }^{2}$, Таращенко Ю. Н. \\ ${ }^{1}$ ГУ «Институт эндокринологии и облена веществ им. В. П. Колисаренка НАМН Украинь»,, \\ г. Киев, Украина; \\ ${ }^{2}$ Наииональный университет пищевых технологий, г. Киев, Украина \\ igorluz@bigmir.net
}

Обследовано 61 жителей из пострадавших после Чернобыльской аварии районов Житомирской области: из них 45 без тиреоидной патологии - контрольная группа, и 16 из с аутоиммунным тиреоидитом - опытная группа. Все обследованные с дозой облучения щитовидной железы (ЩЖ) < $0,3 Г р-$ $\geq 1$ рр, участники когортных исследований Украинско-Белорусского-Американского проекта.

Состояния щитовидной железы исследовали с помощью сканера Terason 2000 с линейным датчиком частотой 10 МГц. Опредепение концентрация йода в образцах мочи проводилось методом SandellKolthoff в модификации Dunn. Функциональное состояние ЩЖ оценивали по содержанию тиреотропного гормона (ТТГ) и свободного тироксина (cТ4) тиреоглобулина (ТГ) в сыворотке крови методом радиоиммунного анализа. Исследования уровней антител к тиреоглобулину и тироксин-пероксидазы в сыворотке крови проводили с помощью иммуноферментного метода.

При исследовании показателей тиреоидного статуса группа пациентов с аутоиммунным тиреоидитом отличалась от контроля увеличенным тиреоидным объемом, повышенным уровнем антител к тиреопероксидазе и повышенным уровнем тиреотропного гормона. Медиана экскреции йода с мочой в исследованных группах достоверно отличалась $(\mathrm{p}<0,05)$, её показатель в контрольной группе составил 80,5 мкг/л, в опытной группе 51,7, что указывало на наличие йододефицита слабой степени.

Концентрации кальция, магния, цинка, меди, железа и селена в образцах сыворотки крови определяли методом оптико-эмиссионной спектроскопии с индуктивно связанной плазмой (ИСП-ОЭС, Perkin-Elmer, модель Optima 2100, США). В обследованных пациентов с аутоиммунным тиреоидитом установлено более низкое ( $<0,001)$ содержание магния, кальция, цинка и меди в сыворотке крови по сравнению с соответствующим показателем в контрольной группе.

Относительный риск развития АИТ при низком содержании магния $(\mathrm{P}<0,001)$ составил $\mathrm{RR}=5,4$ (95\% ДИ 2,7-8,8), при низком содержания кальция - 2,9 (95\% ДИ 1,8-3,6) (P < 0,001) и при низком содержании цинка - 2,3 (95\% ДИ 1,6-2,6) (P < 0,01).

К л ючевые сл о в а : йодный дефицит, щитовидная железа, аутоиммунный тиреоидит, экскреция йода с мочой, макро- и микроэлементы, относительный риск возникновения заболевания.

\section{ТИРЕОЇДНИЙ СТАТУС, ВМІСТ МАКРО- ТА МІКРОЕЛЕМЕНТІВ У ПАЦІЄНТІВ 3 АУТОІМУННИМ ТИРЕОЇДИТОМ З ПОСТРАЖДАЛИХ ПІСЛЯ ЧОРНОБИЛЬСЬКОÏ АВАРІЇ РАЙОНІВ ЖИТОМИРСЬКОÏ ОБЛАСТІ}

\author{
Лузанчук I. А. ${ }^{1}$, Кравченко В. І. ${ }^{1}$, Полумбрик М. О. ${ }^{2}$, Таращенко Ю. М. \\ ${ }^{1}$ ДУ «Інститут ендокринологї та обліну речовин іл. В. П. Колісаренка НАМН України», \\ м. Київ, Украӥна; \\ ${ }^{2}$ Національний університет харчових технологї̈, м. Київ, Україна \\ igorluz@bigmir.net
}

Обстежено 61 мешканців з постраждалих після Чорнобильської аварії районів Житомирської області: з них 45 без тиреоїдної патології - контрольна група, та 16 з із автоімунним тиреоїдитом - до-

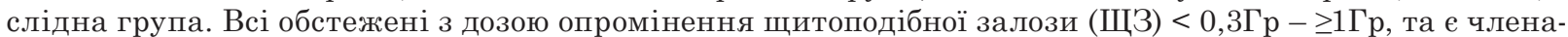
ми когортних досліджень Українсько-Білорусько-Американського проекту.

Проводились ультразвукові дослідження стану ЩЗ сканером Terason 2000 з лінійним датчиком частотою 10 мГц, визначення вмісту йоду в сечі — церій-арсенітним методом Sandell-Kolthoff в модифікації Dunn. Функціональний стан ЩЗ досліджували за вмістом тиреотропного гормону (ТТГ), вільного тироксину (в $\left.\mathrm{T}_{4}\right)$, тиреоглобуліну (ТГ) в сироватці крові методом радіоімунного аналізу. Дослідження рівнів антитіл до тиреоглобуліну та тироксин-пероксидази в сироватці крові проводили імуноферментним методом.

При дослідженні показників тиреоїдного статусу група паціентів з аутоімунним тиреоїдитом відрізнялась від контролю збільшеним тиреоїдним об'ємом, підвищеним рівнем антитіл до тиреопероксидази та підвищеним рівнем тиреотропного гормону. Медіана екскреції йоду з сечею в досліджених групах достовірно відрізнялась ( $<0,05)$, їі показник в контрольній групі становив 80,5 мкг/л, в дослідній групі 51,7 що вказувало на наявність йододефіциту слабкого ступеня.

Концентрацію кальцію, магнію, цинку, міді, заліза та селену в зразках сироватки крові визначали методом оптично-емісійної спектроскопії з індуктивно зв'язаною плазмою (ІЗП-OEC, Perkin-Elmer, 
модель Optima 2100, США).У обстежених паціентів з аутоімунним тиреоїдитом встановлено знижений ( $<<0,001)$ рівень магнію, кальцію, цинку та міді в сироватці крові у порівнянні з відповідним показником у контрольній групі.

Відносний ризик розвитку АIT при низькому вмісту магнію $(\mathrm{P}<0,001)$ становив $\mathrm{RR}=5,4(95 \%$ ДІ 2,7-8,8), при низькому вмісту кальцію - 2,9 (95\% ДІ 1,8-3,6) (Р < 0,001) та при низькому вмісту цинку - 2,3 (95\% ДІ 1,6-2,6) (Р<0,01).

К л ючові слова: йодний дефіцит, щитоподібна залоза, автоімунний тиреоїдит, екскреція йоду із сечею, макро- та мікроелементи, відносний ризик виникнення захворювання.

\title{
THYROID STATUS, MAJOR AND TRACE ELEMENTS CONTENT IN PATIENTS WITH AUTOIMMUNE THYROIDITDIS LIVING IN CHERNOBYL-AFFECTED AREAS OF ZHYTOMYR REGION
}

\author{
I. A. Luzanchuk ${ }^{1}$, V. I. Kravchenkoํ, M. O. Polumbryk ${ }^{2}$, Yu. M. Tarashchenko \\ ${ }^{1}$ Institute of endocrinology and metabolism of NAMS of Ukraine, Kyiv, Ukraine; \\ ${ }^{2}$ National University of food technologies, Kyiv, Ukraine \\ igorluz@bigmir.net
}

Fifteen patients with autoimmune thyroiditis (AIT) and 45 individuals without thyroid pathology comprising control group were examined for the $\mathrm{Ca}, \mathrm{Mg}, \mathrm{Zn}, \mathrm{Fe}, \mathrm{I}$, Se, $\mathrm{Cu}$, thyroid dose, and thyroid status in the biological samples (blood serum and urine). The AIT group was exposed to radioactive doses of radiation, which exceed $1 \mathrm{~Gy}$, whereas participants in the control group were exposed to less than 0.3 Gy during Chernobyl disaster. The individuals mentioned above participated in the cohort of US-Ukrainian-Belorussian collaborative project, and their blood samples were obtained from the database.

In the present study, thyroid gland sizes were examined using a real-time portable scanner (Terason 2000, Burlington, MA, USA) with linear transducer, and frequency of $10 \mathrm{MHz}$. Iodine concentration in urine samples was measured by Sandell-Kolthoff reaction with the Dunn's modification. Thyroid hormones status was assessed by concentrations of: thyroid stimulating hormone (TSH), free thyroxine (FT4) and thyroglobulin (Tg) in serum by radioimmunoassay analysis. Concentration of thyroglobulin antibodies (TgAbs) and thyroxine peroxidase antibodies (TPOAb) were measured in serum by immunochemiluminescence assays.

Significantly higher parameters of the thyroid gland volume (Tvol), thyroxine peroxidase antibodies (TPOAb), and thyroid stimulating hormone (TSH) in blood serum were observed in the patients with AIT as compared to the control group. The median level of urinary iodine excretion urine (UIE) in the AIT group was significantly higher $(\mathrm{p}<0.05)$ as compared to control group, which indicated the presence of mild iodine deficiency in the AIT group.

Concentrations of calcium, magnesium, zinc, copper, iron, and selenium in serum were determined by atomic optical emission spectrometry coupled by inductively coupled plasma (ICP-OES, Perkin-Elmer, model Optima 2100 , USA). In this study, patients with AIT had statistically significant ( $<0.001$ ) lower level of $\mathrm{Mg}, \mathrm{Ca}, \mathrm{Zn}$, and $\mathrm{Cu}$ in blood serum than in the control group.

The relative risk $(\mathrm{RR})$ of AIT development AIT low magnesium content in blood serum $(\mathrm{p}<0.001)$ was $\mathrm{RR}=5.4(95 \%$ CI 2.7-8.8), AIT low calcium content relative risk of AIT was $2.9(95 \%$ CI 1.8-3.6) $(\mathrm{p}<0.001)$, and AIT low zinc content RR of AIT was found to be 2.3 (95\% CI 1.6-2.6) $(\mathrm{p}<0.01)$.

Keywords: iodine deficiency, thyroid gland, autoimmune thyroiditis, urinary iodine excretion, thyroid dose, trace elements, relative risk. 